\title{
ERROR MADE IN CONVERSATION BY INDONESIAN LEARNERS LEARNING ENGLISH BASED ON SYNTAX AND EXCHANGING INFORMATION
}

\author{
Melania Wiannastiti \\ English Departement, Faculty of Humanities, BINUS University \\ Jln. Kemanggisan Ilir III No.45, Kemanggisan - Palmerah, Jakarta 11480 \\ mwiannastiti@binus.edu
}

\begin{abstract}
In learning a second language or foreign language (L2), learners should master the competences. Normally, L2 learners first should master the linguistic competence which includes the mastery of vocabularies, pronunciation, and grammar. The study is to find out the syntax error made by L2 learners in conversation as well as to find out the exchanging information. The data were the recording conversation of Visual Communication Design students first semester of Binus University joining English Entrant. Error analysis was used to analyze the data. There are two points of view to analyze the data: syntax from taxonomy and exchanging information. Taxonomy employs the error in omission, addition, misinformation, and mis-ordering. Exchanging information point of view employs the error in finite element and mood. The result shows that L2 learners made some errors in grammar and exchanging information because they are influenced by the L1. They tend to transfer from L1 to L2 rather than thinking to create the utterances in L2.
\end{abstract}

Keywords: second language, Linguistics, linguistic competence, Linguistic Category Taxonomy

\begin{abstract}
ABSTRAK
Dalam pemelajaran bahasa kedua atau bahasa asing, pembelajar dituntut untuk menguasai kompetensi berbahasa yang diharapkan. Pada umumnya, pembelajar bahasa asing harus menguasai kompetensi linguistik yang mencakup penguasaan kosakata (vocabularies), pelafalan (pronunciation), dan tata bahasa (grammar). Berdasar pada kompetensi tersebut, penelitian ini ditujukan untuk mencari kesalahan linguistik yang dibuat pembelajar ketika sedang bercakap-cakap dan untuk mencari apakah mereka sudah melakukan tukar informasi (exchanging information) secara benar. Data yang dianalisis adalah rekaman mahasiswa jurusan Desain Komunikasi Visual, Universitas Bina Nusantara semester satu yang mengambil mata kuliah English Entrant. Satu kelas terdiri dari delapan mahasiswa. Ada dua sudut pandang yang digunakan untuk menganalisis data, yaitu dari segi kesalahan sintaksis (taksonomi) dan tukar infomasi. Segi taksonomi melihat kesalahan penghilangan kata (omission), penambahan kata (addition), kesalahan informasi (misinformation), dan salah penempatan (mis-ordering). Segi tukar informasi menyoroti peggunaan mood element dan finite. Hasil yang didapat adalah pembelajar bahasa kedua/asing melakukan kesalahan dalam tata bahasa karena dipengaruhi bahasa pertama-dalam hal ini Bahasa Indonesia. Mereka cenderung hanya mentransfer bahasa pertama ke bahasa kedua tanpa memerhatikan tata bahasa kedua (L2).
\end{abstract}

Kata kunci: bahasa kedua, Linguistik, kemampuan linguistik, Taksonomi Kategori Linguistik 


\section{INTRODUCTION}

Communication by using a language means that the speaker should have ability to use the language properly. To be able to use it properly a speaker should master the language competence which includes grammatical or linguistics, discourse and sociolinguistics competences. Ideally, a speaker of a language masters all of them. However, for some reasons, a speaker tends to ignore or miss to use all of them since they are in the context of situation in which a speaker or a listener understands the situation. It means that both of them agree on a situation without being spoken.

In learning a second language or foreign language (L2), learners should master the competences. Normally, L2 learners first should master the linguistics competence which includes the mastery of vocabularies, pronunciation, and grammar. All those elements are needed simultaneously. It is not easy for the learner to master them at once. They need some adjustment, especially when they have to rely on their first language (L1). The background of their first language influences the intonation, pattern of sentences and vocabularies they use.

It is common that L2 learners make some errors in using the second language in communication as Ellis (1994) said that learners make errors in both comprehension and productions. Most of L2 learners are influenced much by the L1 acquisition. Since language is a habit, the L1habit will influence someone in learning L2. It assumes that one biggest factor interferes the learner in learning second language is 'habit'. The underlying assumption of CA was that error occurred primarily as a result of interference when the learner transferred native language (L1) 'habits' into the L2” (Ellis, 1994).

The previous research done by Heydari (2012), Lopez (2014), and Huang (2014) mentioned that in achieving L2, students tends to make some errors and also are influenced by the L1. Students in Iran, Mexico and Taiwan face the same problem that they mostly made mistakes in grammar because of the influences of their mother tongue or L1.

This paper is based on the linguistics competence and exchanging information points of view to see how L2 learners struggled to produce correct L2 which in fact is still influenced by the L1. There are two objectives in doing this study; first, to find out syntactic errors made by students based on taxonomy points of view; second, to find out syntactic errors based on exchanging information.

\section{Theoretical Framework}

Some linguists examine the errors made by L2 learners in achieving the target language used error analysis. Most of the linguists paid attention a lot on the two cases of learners' production, i.e. oral and written production. Errors are the flawed side of learner speech or writing. They are those parts of conversation composition that deviate from some selected norm of mature language performance. (Dulay, Burt, \& Krashen, 1982:138)

In linguistics competence, most L2 learners make error almost in the same way. There are some categories are said to be common errors:

- Omitting grammatical morpheme

L2 learners omit some morpheme although contextually it does not really contribute much to the meaning of sentences. Example: He kick the ball. A morpheme (-s or -ed) needs to add in the verb 'kick' to make the context of situation easy to understand.

- Double marking a semantic feature.

It happens when only one marker is required, but L2 learners use double such as in She didn't went back.

- $\quad$ Regularizing rules, as in woman for women

- Using archiform, one form in place of several, such as the use of her in the sentence I see her yesterday. Her danced with my brother. 
- Using two or more forms in random alternation, as the using of him and her, regardless of the gender of the person of interest.

- $\quad$ Misordering items as in They are all the time late. (Dulay, Burt, \& Krashen, 1982:138 -139)

Many error taxonomies have been based on the linguistic items, which are affected by an error. These linguistic category taxonomies classify errors according either or both language component or particular linguistic constituent the error affect. Linguistics items are phonology, morphology, syntax and semantic. Dulay, Burt, and Krashen (1982:146) divides the items into more complete one, i.e. phonology (pronunciation), syntax and morphology (grammar), semantic and lexicon (meaning and vocabulary) and discourse (style). Dulay, Burt and Krashen (1982) made sample Linguistic category taxonomy as follows:

Table 1 A Sample Linguistic Category Taxonomy in Syntax

\begin{tabular}{|c|c|c|}
\hline \multicolumn{3}{|c|}{ SYNTAX } \\
\hline \multirow[t]{22}{*}{1} & \multirow{2}{*}{\multicolumn{2}{|c|}{$\begin{array}{l}\text { NOUN PHRASE } \\
\text { a. Determiners }\end{array}$}} \\
\hline & & \\
\hline & - Omission of the article & He no go in the hole \\
\hline & - Substitution of definite article for possessive pronoun & He fall down on the head \\
\hline & - Use of possessive with the article & He put it in the his room \\
\hline & - Use of wrong possessive & The little boy hurt its leg \\
\hline & \multicolumn{2}{|l|}{ b. Nominalization } \\
\hline & - $\quad$ Simple verb used instead of -ing & By to cook it \\
\hline & • $\quad$ Preposition by omitted & $\begin{array}{l}\text { The dove helped him by putting leaf on the } \\
\text { water }\end{array}$ \\
\hline & \multicolumn{2}{|l|}{ c. Number } \\
\hline & - $\quad$ Substitution of singulars to plurals & He got some leaf \\
\hline & - $\quad$ Substitution plurals for singulars & He step him in the feet \\
\hline & \multicolumn{2}{|l|}{ d. Use of Pronoun } \\
\hline & - Omission of the subject pronoun & (he) pinch the man \\
\hline & - Omission on the "dummy" pronoun it & Is nice to help people \\
\hline & - Omission of the object pronoun & I don't know (it) in English \\
\hline & - Subject pronoun used as a redundant element & My brother, he go to Mexico \\
\hline & - Alternating use of pronouns by number as well as gender & So she can eat it (referring to apples) \\
\hline & - Use of meas subject & Me forget it \\
\hline & \multicolumn{2}{|l|}{ e. Use of preposition } \\
\hline & - Omission of preposition & He came (to) the water \\
\hline & - $\quad$ Misuse of preposition & He fell down from (on, into?) the water. \\
\hline \multirow[t]{12}{*}{2} & \multicolumn{2}{|l|}{ Verb Phrase } \\
\hline & \multicolumn{2}{|l|}{ a. Omission of verb } \\
\hline & - Omission of the main verb & He (fell) in the water \\
\hline & - Omission of to be & He in the water \\
\hline & \multicolumn{2}{|l|}{ b. Use of progressive tense } \\
\hline & - Omission of be & He going \\
\hline & - $\quad$ Replacement of ing by simple verb form & The bird was shake his head \\
\hline & - Substitution of the progressive for simple past & Then the man shooting (shot?) with the gun \\
\hline & \multicolumn{2}{|l|}{ c. Agreement of subject and verb } \\
\hline & - $\quad$ Disagreement of subject and verb & You be friends \\
\hline & - Disagreement with subject and number & The apples was coming down \\
\hline & - Disagreement with subject and tense & I didn't know what it is \\
\hline \multirow[t]{5}{*}{3} & \multicolumn{2}{|l|}{ Verb- and -verb construction } \\
\hline & - Embedding of a noun- and -verb construction in another & I go to play (I go and I play) \\
\hline & noun- and -verb construction & I go play \\
\hline & - Omission of to in identical subject construction & I see a bird got the leaf \\
\hline & $\begin{array}{l}\text { - } \quad \text { Omission on to in the verb- and verb construction } \\
\text { - }\end{array}$ & He was going to fell \\
\hline
\end{tabular}


Table 1 A Sample Linguistic Category Taxonomy in Syntax (continued)

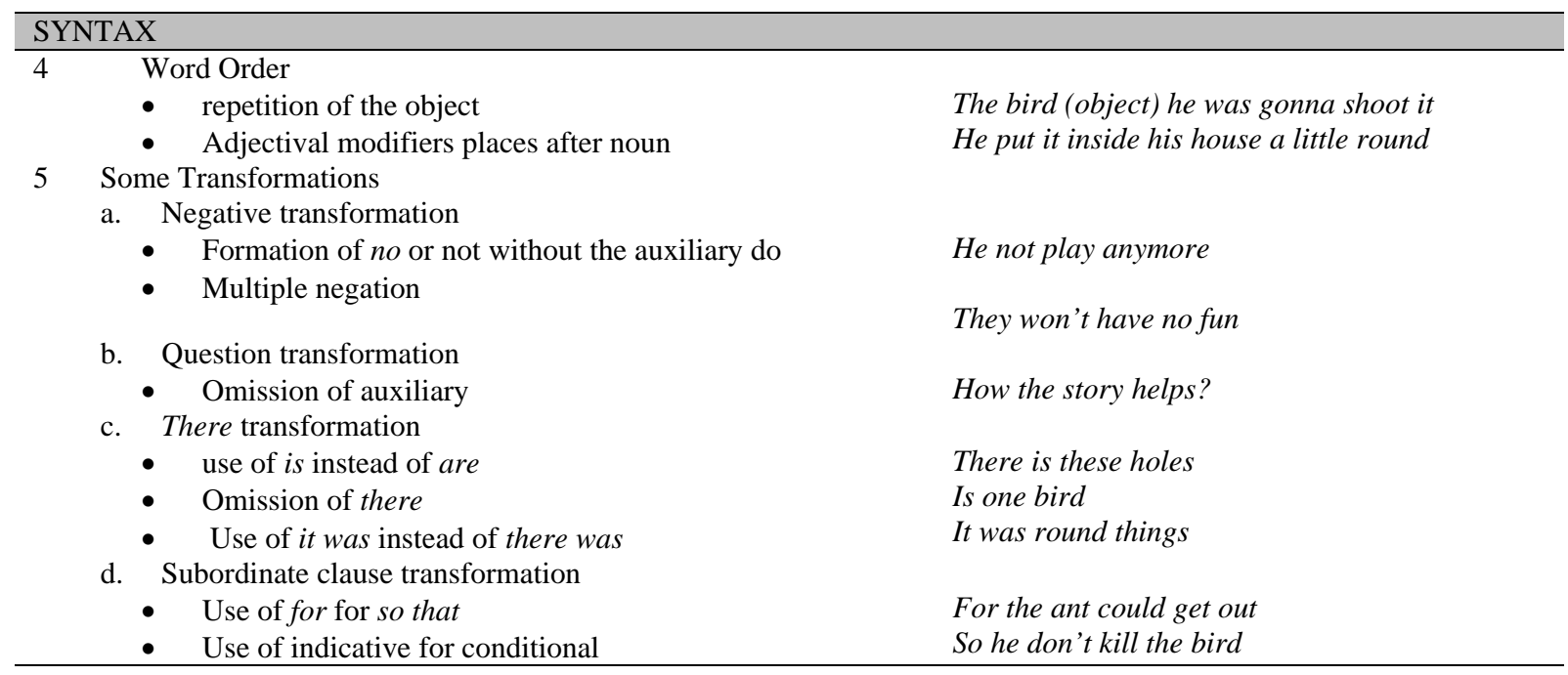

(Dulay, Burt, Krashen, 1982:148-150)

According to Halliday and Mathiessen (2014) grammar is the central processing unit of language, the power house where meanings are created. L2 learners often think that grammar is not the most important thing in learning the second language. They often deny the importance of using the correct grammar. Therefore, the meaning cannot be conceived. If they have to speak with the native speaker, they are often confused with what the learners mean.

In linguistic competence of L2, besides the taxonomy based analysis, the grammatical analysis, which is called lexico-grammar was introduced by Halliday said that a grammatical analysis treats linguistic items not as expression but as a form (2014:17). He emphasized the form of creating the correct form which is meaningful.

In the case of clause of exchange or exchanging information Eggins (2005) and Halliday and Mathiessen (2014) have the same idea that in speech, the speaker either giving something to the listener or he is demanding something from him. To make the speech more meaningful, both Halliday and Eggins said that the Mood element is the most important to convey the message. Mood element consists of Subject and Finite.

According to Halliday and Mathiessen (2014) a subject is a word(s) when it first appears or maybe any nominal group and the finite element is one of a small number of verbal operators expressing tense or modality" While Eggins (1994) said that there are three main elements to the mood constituent: (1) an expressions of polarity, either YES (positive polarity) or NO (negative polarity); (2) A nominal-type element, which we will call SUBJECT; and (3) A verbal- type element, which we call the FINITE.

Klein (1986) mentioned that the finite element is that part of the verbal complex which marks tense, number, and person; it may be contained in the verb itself come, or consist of an auxiliary verb (has gone), or involve a modal verb (should have gone) (p.90). Moreover, he continued his opinion about how the L2 learner gets difficulties in applying finite element because the learners are influenced by their first language. The finite element and its potential properties cannot simply be identical by analyzing the input according to the first language knowledge” (Klein, 1986:92) 


\section{METHOD}

The subject data for the study were the first semester students learning English Entrant, a part of compulsory general English at Bina Nusantara University in the odd semester 2013. This mini research was carried out in one class which consisted only with eight students. All students in this class were asked to record their conversation in pairs for about $3-10$ minutes with free topic of their interest. The recorded conversations then were transcribed and coded. After the data were coded then they were jotted down based on the errors made by the students. This jotting down data was then used as the data to be analyzed.

In analyzing data, qualitative method was used by grouping the errors made by the L2 learners. The data was analyzed based on two points of view; first it was based on error of taxonomy and second was based on the exchanging information. The exchanging information analysis was based on the mood elements.

\section{RESULTS AND DISCUSSION}

The discussion was based on two different points of view. The first one is based on the errors made by the students/ learners on the point of view of syntactical taxonomy and the second one is based on the grammatical errors of the exchanging information.

\section{Syntactical Errors from the Taxonomy}

From the point of view of taxonomy which consists of four categories: omission, addition, misinformation and misordering, here is the finding (Table 2).

Table 2 Syntactical Errors from the Taxonomy

\begin{tabular}{|c|c|c|}
\hline no & categories & Students sentences \\
\hline 1 & $\begin{array}{l}\text { Omission } \\
\text { The words inside the ( ) } \\
\text { - } \text { Pronoun } \\
\text { - to be } \\
\text { - } \text { to } \\
\text { - } \text { preposition } \\
\text { - } \text { Auxiliary verb }\end{array}$ & $\begin{array}{ll}\text { ds } & \\
\text { - } & \text { Not ... (it's ) not him } \\
\text { - } & \text { After (I) wake up, I usually .... } \\
\text { - } & \text { I have a little brother not a girl but he (is) a boy } \\
\text { - } & \text { Speaking (is) at } 8 \text { o'clock and then writing (is) at } 2 \text { p.m } \\
\text { - } & \text { (Are) You watching TV? } \\
\text { - } & \text { And after that where you have (to) go? } \\
\text { - } & \text { I want to.. to invite you (to) a movie } \\
\text { - } & \text { I usually hmm (take a) bath and clean } \\
\text { - } & \text { Where (will/do) we watch movie } \\
\text { - } & \text { And after that where (do) you have (to) go? }\end{array}$ \\
\hline 2 & $\begin{array}{l}\text { Addition } \\
\text { The underlined wo } \\
\text { - } \quad \text { tag-question } \\
\text { - } \quad \text { preposition }\end{array}$ & 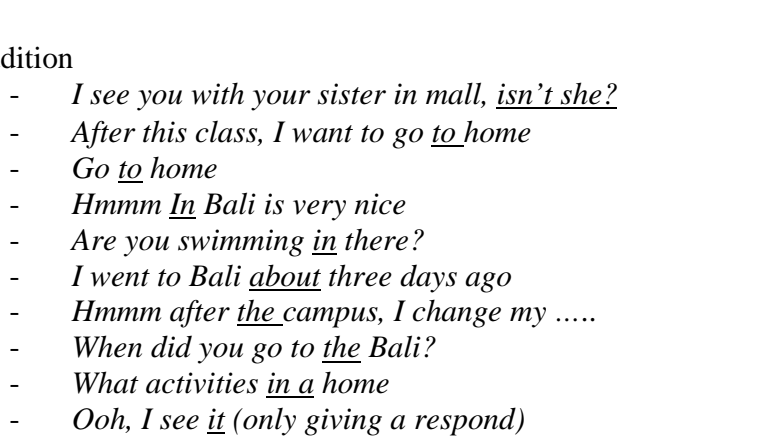 \\
\hline
\end{tabular}


Table 2 Syntactical Errors from the Taxonomy (continued)

\begin{tabular}{|c|c|c|}
\hline no & categories & Students sentences \\
\hline 3 & $\begin{array}{l}\text { Misinformation } \\
\text { The underline word are the misinform } \\
\text { - } \text { agreement of verb tense } \\
\text { substitution of progressive to } \\
\text { present form } \\
\text { - Indicative the using 'so' } \\
\text { - Question transformation } \\
\text { - use the wrong possessive } \\
\text { - use the wrong pronoun } \\
\text { use the wrong preposition }\end{array}$ & 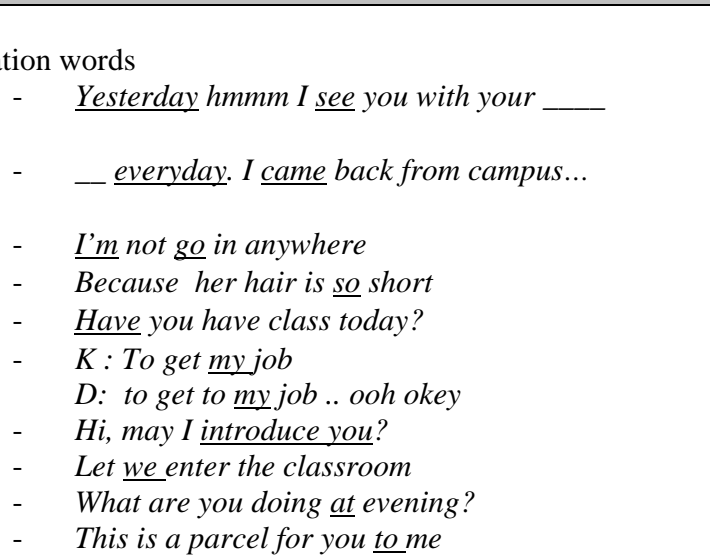 \\
\hline 4 & $\begin{array}{l}\text { Misordering } \\
\text { The sentences in ( ) are the correct ones } \\
\text { - incomplete sentence }\end{array}$ & $\begin{array}{l}\text { - What other? (What other activities do u do?) } \\
\text { - What activities in a home } \\
\text { (What activities do you do at home?) } \\
\text { - Hmmm beautiful scenery } \\
\text { (It has beautiful scenery) } \\
\text { - Hmmm maybe back from job at night } \\
\text { (Hmm maybe after I come back from job at night) }\end{array}$ \\
\hline
\end{tabular}

From the finding, it can be gained some analysis based on each part of errors.

\section{Omission}

The omission done by the learner was influenced by the L1 language .i.e. Bahasa Indonesia (BI). Such as in these sentences.
(a) $\quad E:$ Not (it's ) not him
BI: Bukan....... Bukan dia

In (a), the student omitted the subject and finite as shown in the brackets. S/he was influenced by the use Bahasa Indonesia. The utterance shown is accepted and does not change the meaning. The same as in (a), the following utterances were made by the students in (b), (c), (d) and (e). All examples give the idea that they were influenced by the Bahasa Indonesia as their L1. In Bahasa Indonesia, normally there is no auxiliary verb used.
(b) E: After (I) wake up, I usually....
BI: Setelah bangun, saya biasanya........
(c) E: but he (is) a boy
BI: tapi dia anak laki-laki
(d) E: (Are) You watching TV?
BI: Kamu menonton TV?
(e) E: Where (will/do) we watch movie?
BI: Di mana kita menonton film? 
In (b), the student omitted the subject, while in (c) the student omitted the auxiliary verb. The same as in (c), in (d) the student miss the auxiliary verb to ask a question.

From the discussion above, it can be said that L2 learners usually transfer the L1 rules to the L2 one. Some omissions on pronoun, to be, and auxiliary verb were used by the L2 learners.

\section{Addition}

In this part, students tend to add some expression or mostly preposition as it can be seen for the following examples.

(f) E : I see you with your sister in mall, isn't she?

BI: Saya melihat kamu dengan adikmu di mall, ya kan?

There is different rule in Bahasa Indonesia in using tag question from the English one. Because tenses in Bahasa Indonesia is represented differently than in English, in which Bahasa Indonesia represents its tenses in adverbial phrase and not in the changing form of the verbs. In BI, all type of tag question is translated into 'ya kan' no matter what tenses used in English. Therefore, it is understood that it is not easy for the learners to apply the different types of tag question.

Examples (g), (h), (i) show that the problem happens in the use of preposition. In English, to refer to a place sometimes is not necessary to put a preposition before the place such as in the words: (g) home and (h) there. On the contrary, in BI to refer to a place a preposition is needed.

(g) E: After this class, I want to go to home

BI: Setelah kelas ini, saya ingin pulang ke_rumah

(h) E: Are you swimming in there?

BI: Apa kamu berenang di sana?

(i) E: I went to Bali about three days ago

BI: Saya pergi ke Bali kira-kira tiga hari yang lalu.

From the discussion above, it can be seen that the addition of preposition occurred because they still transferred the L1 rules to the L2. In (g), the preposition 'to' was used to replace BI of 'ke', and in (h), the word there was translated in BI into two words 'ke' as the preposition and 'sana' as the place over there.

\section{Misinformation}

In this part, there are some errors made by the learner. Most of them are caused by some differences rules of grammar, especially tenses. The acquisition of tense will be very difficult for the learners since there are quite big difference rules between the two languages.

(j) E: Yesterday hmmm I see you with your

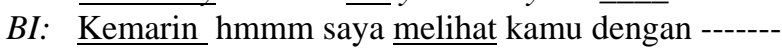

(k) E: Today I see you in a mall

BI: Hari ini saya melihat kamu di mall

In Bahasa Indonesia, the difference of the time (tenses) is indicated by the time marker. Such as in yesterday: kemarin, tomorrow: besok, today: hari ini, but the form of the verb remains the same. Thus, the examples in (j) and (k) show that the students did not change the verb form but either placed the time markers yesterday in ( $\mathrm{j}$ ) and today in $(\mathrm{k})$ 


\section{Mis-ordering}

In this part, the incomplete sentences were made by the learners. These errors are still influenced by the rules of the L1 language. The misordering can be found in the following example.

(l) E : What activities in a home?

BI: Apa kegiatan di rumah?

In Bahasa Indonesia, both utterances are incomplete. In the context of situation the utterance (l) in Bahasa Indonesia in which the speaker and listener agreed that the question was about present time. Therefore, the learners did not bother to complete the utterances in the complete one.

\section{Grammatical Errors from the Exchanging Information}

The finding based on the exchanging information consists of the part(s) of the clause constitutes the MOOD element which cannot disappear when the responding speaker takes up his/her position (Egginz, 2005:155). Here are the findings (Table 3).

Table 3 Grammatical Errors from the Exchanging Information

\begin{tabular}{|c|c|c|}
\hline & Exchanging Information & The utterances \\
\hline \multirow[t]{2}{*}{1.} & Interpersonal meaning & (a) D: I'm fine. Have you have a class today? \\
\hline & & $K:$ Yes, we have. \\
\hline \multirow[t]{7}{*}{2.} & Missing finite element & (b) D : what time? \\
\hline & & K: Speaking (is) at 8 o'clock and writing (is) at 2 p.m. \\
\hline & & (c) What activities at home? \\
\hline & & (d) I like the movie that if.. that if (it is) action. \\
\hline & & (e) I usually ... (take a) bath and clean \\
\hline & & (f) Where (do/will) we watch movie? \\
\hline & & (e) Of course I have to get a job everyday. I came back from campus... \\
\hline \multirow[t]{3}{*}{3.} & The wrong MOOD & (f) I have not difficult to get a job. \\
\hline & & (g) A : Are you swimming in there? (asking about the past event) \\
\hline & & I : I am not swimming. (Responding the past event) \\
\hline \multirow[t]{2}{*}{4.} & The inappropriate respond & (h) I: Good evening, Agus \\
\hline & & A: Thank you very much. What a nice party you have. \\
\hline \multirow[t]{6}{*}{5.} & The different finite in giving & (i) R: Hi.. may I introduce you ( may I know you) \\
\hline & respond & $C: Y e s, I \underline{d o}$ \\
\hline & & (j) R: What are you doing at home? \\
\hline & & C: At home I help my mother every day. \\
\hline & & (k) C: What are you doing in the evening? \\
\hline & & R: I usually doing homework at home. \\
\hline
\end{tabular}

\section{Interpersonal Meaning}

The different interpersonal meaning occurs in (a) that $\mathrm{K}$ missed the referee in the questions. $\mathrm{K}$ assumed that both $\mathrm{D}$ and $\mathrm{K}$ had the same class, therefore when $\mathrm{D}$ asked using the referee 'you', $\mathrm{K}$ answered by using 'we' rather than using 'I'.

(a) D: I'm fine. Have you have a class today?

$K$ : Yes, we have 


\section{Missing Finite Element}

There are some expressions or utterances that miss the finite elements as in following examples (b), (c), and (d). In (b) the finite element is missing because the learner indicated that tenses were not important. It is because in the context of situation it was understood by them. She assumed that the listener knew that the time is in present.

(b) D: what time?

K: Speaking (is) at 8 o'clock and writing (is) at 2 p.m.

In (c) the speaker or the learner uses this expression because she thinks that the listener understands that what she asks is something about the present. However, the problem can occur when the context is not about the present time and the subject is not the listener.

(c) What activities at home?

There is no finite element in this sentence (d). This error happened because the learner has not acquired the L2 that a bath is a noun, while in the L1 language bath means 'mandi' and it is a verb.

(d) I usually ... (take a) bath and clean

\section{The wrong Mood}

Since the mood element can be since in the subject and finite, it is necessary to place the correct mood in the utterance to be accepted and understood by the listeners. Utterances (e) and (f) are the example of the wrong mood element which is possible to create misunderstanding.

The mood in (e) is said to be wrong because the first utterance indicates that the sentence is in present but the second one is in the past. It is hard to understand the relation between the first and the second one. It also can lead the different meaning.

(e) Of course I have to get a job everyday. I came back from campus...

In (f), the context of situation is s/he went to a place where there was a swimming pool. They met after the visit. All discussion was about the past even. However both of them used present time to discuss which was blatantly incorrect. The question is in the present time as if the activity in of swimming was still in progress.

(f) A: Are you swimming in there? (asking about the past event)

I : I am not swimming. (Responding the past event)

\section{The Inappropriate Respond}

The inappropriate respond is shown in (g). When $I$ greeted $A$, I gave inappropriate respond. He did not answer the question but said something else. He should answer I's greeting by saying "Good evening”

(g) I: Good evening, Agus?

A: Thank you very much. What a nice party you have. 


\section{Different Finite Respond}

The different respond also occurs in the following conversation (h) and (i). From the conversation in (h) and (i), it can be seen that responding someone's utterance is not easy for the L2 learners. The first example indicates that the finite is not importance for them as long as she answered with "YES" which indicates the agreement.

The second example proves that the finite element is not an easy thing to master as the first speaker asking about in progress activity in present progressive and the second person answer in present tense. In English, both of the tenses have different situation of an event.

(h) R: Hi.. may I introduce you ( may I know you)

C: Yes, I $\underline{\mathrm{do}}$

(i) R: What are you doing at home?

C: At home I help my mother everyday.

\section{CONCLUSION}

From the discussion, it can be concluded that Indonesian learning L2 made some errors in the grammatical pattern (based on taxonomy point of view) because they are influenced by the L1 pattern they acquired before. They made many omissions and additions of sentences. On the other hand, on the point of view of exchanging information, Mood elements are not easy to acquire. Finite element is also the thing that they never pay attention too much. This is because in L1, they do not have tenses and finite element that are very important in L2.

Knowing the result, L2 should aware that those elements are very important in learning the L2, especially when they talk to the native speakers. Without those elements, English speaking people will get difficulties in understanding what the L2 learner means. Beside the L2 learners, the L2 teachers should also consider the importance in emphasizing the finite element and the taxonomy pattern for the L2 learners.

\section{REFERENCES}

Dulay, H., Burt, M., and Krashen, S. (1982). Language Two. Oxford: Oxford University Press.

Eggins, S. (2005). An Introduction to Systemic Functional Linguistic. $2^{\text {nd }}$ Edition. London: Pinter Publisher.

Ellis, R. (2003). Learner Error and Error Analysis. In Understanding Second Language Acqusition. $2^{\text {nd }}$ Edition. Oxford: Oxford University Press.

Halliday, MAK, and Mathiessen, C. (2014). An Introduction to Functional Grammar. $4^{\text {th }}$ Edition. New York: Routlegde

Heydari, P. (2012). Error analysis: sources of L2 learners errors. Journal Theory and Practice in Language Studies, 2(8), 1583-1589. DOI:10.4304/tpls.2.8.1583-158. ISSN: 1799-2591. 
Huang, J. (2014). Error Analysis in English Teaching: A Review of Studies. Retrieved from: http://lib.csghs.tp.edu.tw/\%E4\%B8\%AD\%E5\%B1\%B1\%E5\%A5\%B3\%E9\%AB\%98\%E5\%A D\%B8\%E5\%A0\%B1\%E7\%AC\%AC\%E4\%BA\%8C\%E6\%9C\%9F/03ERROR\%20ANALYSI $\underline{\text { S.pdf }}$

Klein, W. (1986). Second Language Acquisition. Cambridge: Cambridge University Press.

López, W. C. (2014). Error Analysis in Learner Corpus What Are The Learners' Strategies? I Congreso Internacional de Lingüística de Corpus (CILC'09). Retrieved from http://www.um.es/lacell/aelinco/contenido/pdf/45.pdf 